\title{
Desafios às Ciências Sociais de Língua Portuguesa*
}

\section{FLORESTAN FERNANDES**}

o cumprir setecentos anos, a Universidade de
Coimbra liga antigos dias de glória, de Portugal e de
sí própria, a uma época grandiosa mas de incertezas.

Portugal, que já foi um grande Império e nação hegemônica, volta a ter perspectivas na Europa integrada e no sistema capitalista mundial de poder. De Portugal originou-se uma das grandes revoluçóes históricas: os descobrimentos alteraram a compreensão do mundo e da posiçáo do homem no cosmos. Hoje, vivemos uma era análoga. Os computadores, a automação, a energia nuclear, a bioengenharia, a química fina, os meios de conquista do espaço sideral, etc., ocasionam o mesmo efeito. A rotina não foi abalada, pois os seres humanos ainda não se deram conta que transpuzeram em massa os limites da civilização gerada pelo capital, pela ciência e pela tecnologia científica. Esta respeitável Universidade, contudo, deslocou-se de seu centro de gravidade filosófica, enfrentando tarefas muito complexas, que a compelem a redefinir seus rumos e papéis criadores na órbita da civilização emergente.

A invenção de uma comunidade científico-social tricontinental de língua portuguesa constitui um salto nessa direção, dado corajosamente pelo Centro de Estudos Sociais, pela Faculdade de Economia e pela Universidade de Coimbra. O nosso passado e o nosso presente são ricos em mitos - e mitos que logram passar como verdades, por suas origens, duraçăo secular e enraizamento em concepçóes de mundo arraigadas. Para formar essa comunidade científico-social tricontinental precisamos, primeiro, ir às raizes desses mitos e virá-los pelo avesso. São célebres as reflexōes de Francis Bacon sobre os idola e como eles bloqueiam a percepção e a explicação da

\footnotetext{
* Discurso feito pelo autor no dia 04 de julho de 1990, ao receber o título de Doutor Honoris Causs da Universidade de Coimbra (Portugal).

* Florestan Fernandes é sociólogo e deputado federal (PT-SP).
} 
realidade. Não devemos reduzir a zero nossa herança cultural. Questionando e desmascarando os mitos chegaremos, todavia, à verdade aproximada e sobre ela poderemos edificar as pontes de um conhecimento objetivo, que desvende no que e por que formamos uma comunidade do tipo assinalado.

Trata-se de uma comunidade que náo pode fundar-se, somente, na língua portuguesa. Táo pouco poderia assentar-se no passado longínquo e recente, no qual colonizador e colonizado se opuzeram com vários graus de intensidade e de violência. E sequer alimentar-se de esperanças e promessas nascidas dos tempos que correm e da necessidade de procurarmos os laços de um futuro, que terão de confundir-se e de entrelaçar-se por uma questáo de honra e sobrevivência. Existem valores compartilhados. Também subsistem, muito vivos ou débeis, ódios, incompreensóes e equívocos. A comunidade prescinde de uma unidade granítica. Ela não se consolida, entretanto, sem remover tais fontes de tensóes e antagonismos. E é preciso que apareçam e persistam sólidos alvos voluntários de um querer comum profundo.

Os desafios de tal comunidade procedem principalmente dos universos sociais em que se diferenciam os três continentes; das limitações das ciências sociais em apanhar totalidades históricas $\mathrm{em}$ vir a ser contrastantes; e de utopias (ou vontades coletivas de negar o existente, de transformar o mundo) que não se entroncam em tradiçóes culturais unívocas. Não há unidade nessa diversidade e o "respeito da autonomia das comunidades científicas nacionais" significa uma fronteira, um terreno além do qual a imaginação científica criadora está tolhida de ir. Um "bom" paradigma científico, sob a atual interdependência da pesquisa empírica, pura e aplicada, não separa, mas unifica teoria e prática. As naçōes que buscam, através da social democracia, a reforma capitalista do capitalismo, as que ainda se agarram ao desenvolvimento capitalista, para expandir a sociedade civil civilizada, a democracia e o Estado de direito, e as que procuram, no socialismo revolucionário, a passagem direta para o padrăo de civilização emergente estáo (ou deveriam estar) igualmente empenhadas em um paradigma que permitisse estabelecer a interaçấo entre teoria e prática.

Em meu entender, essa seria a saída para constituir uma comunidade tricontinental de cientistas sociais de língua portuguesa, capaz de respeitar autonomias intocáveis e, ao mesmo tempo, transcender à pulverização. Em outras palavras, descobrir a unidade na diversidade do modo que ela é acessível às ciências sociais e corresponder ao imperativo da mudança social progressiva ou revolucionária que o 
conhecimento científico carrega consigo, como conseqüência, efeito elaborado pelos agentes coletivos ou potencialidade intrínseca. Voltamos por esse caminho, à língua portuguesa. No ponto de partida, ela seria apenas um sistema de palavras, um código de símbolos compartilhado, que instrumentaliza a comunicação sem produzir qualquer unidade. No ponto de chegada, a língua portuguesa teria de mediar a unidade e a diversidade. Penetraria no jargáo técnico e se infundiria nos paradigmas de conhecimento científico que se objetivam na explicaçăo e alteraçăo do concreto historicamente dado. A comunidade emergiria, por seu intermédio, do que fazer, do trabalbar juntos e do trabalho intelectual necessário dos cientistas sociais, engolfados em uma cooperação desejada.

Chegamos até aqui separados e ignorando-nos reciprocamente, à mercê das correntes de pensamento e de ação impostos pelas naçóes capitalistas hegemônicas e sua superpotência, os Estados Unidos. A Universidade de Coimbra propóe uma reversão de rota, pela qual a dialética do colonizador e do colonizado é substituida pela dialética da colaboraçăo entre desiguais, que tentam afirmar sua autonomia através do pensamento inventivo e da coalescência das ciências sociais da língua portuguesa. A proposta indica, por si mesma, que dispomos de condiçóes para alcançar o objetivo. As naçóes de língua portuguesa da África, da América Latina e Portugal carecem desses estudos para corrigir e transpor o desenvolvimento desigual e se associarem em um bloco supranacional; e dispöem de recursos institucionais e de pessoal qualificado para colocar as ciências sociais a serviço de seus ideais de solidariedade e de liberdade com igualdade social. 